\title{
FORECASTING METHODOLOGY OF MARITIME PASSENGER DEMAND IN A TOURIST DESTINATION
}

\begin{abstract}
Maritime passenger demand forecasting is a task that is almost always present in the development studies of passenger ports, both due to operational and investment requirements. If a port belongs to a tourist destination, then there is a reasonable intention to use the forecasting model in order to establish the dependence between the passenger and tourist demand. Since the reliability of forecasting depends to a great extent on the quality and availability of data, the forecasting model is often a compromise between the theoretical assumptions and practical possibilities. This paper presents the approach to maritime passenger demand forecasting using a case study of the tourist destination - Poreč, which has been the strongest destination in Croatia regarding tourist traffic for many years. The presented forecasting models can serve as one of the guidelines for further study of the relations between traffic and tourism.
\end{abstract}

\section{KEY WORDS}

forecasting maritime passenger demand, forecasting tourist demand, traffic and tourism

\section{INTRODUCTION}

For many years the town of Poreč has been one of the main support points of the Croatian tourism. In 2006 Poreč was visited by 506 thousand tourists with a high $92 \%$ share of foreign tourists. In the same year 3195 million overnight stays were achieved and thanks to such tourist traffic Poreč is the strongest tourist destination in Croatia.

The today's number of permanent residents of Poreč is estimated at about 20 thousand. Gross national product per capita is about three times greater than the Croatian average.

In a city with such a highly expressed economic orientation towards tourism, a close connection between maritime, i.e. port functions with tourism in a number of interconnected influences is inevitable. Although the Port of Poreč satisfies also the needs of the domicile population, as a long-term orientation of the town of Poreč tourism determines to a great extent the functional requirements that the Port of Poreč has to meet.
The port authorities of Poreč have found it necessary to make a development study for the Port of Poreč that would define the basic urban and traffic concept of the port over a long period of time, satisfying the maritime, traffic, organizational, and spatial aspects of the future development.

One of the set goals of this development study was:

- to estimate / forecast the volume of the passenger demand at the Port of Poreč according to the demand segments, and to determine to which extent (quantitatively and qualitatively) the current port capacities can satisfy the passenger demand in the future.

Solving the concrete task in planning the transport infrastructure (in this case, the passenger port), again the principle question regarding the forecasting range of the transport demand is asked, without which it would be difficult to discuss the needs for the transport capacities in the future. For many decades, the traffic planners have been trying to balance the need to quantify the future transport demand with the need to rationalize the work on the forecasting models regarding time consumption. It has often been the case that the development of the forecasting model consumes more than 30 percent of the total available time for the development of the entire study.

Before the decision on the methodological approach applied in forecasting the transport demand is made, several main relations that occur between the traffic models used to forecast the transport demand and the very procedure of transport infrastructure planning have to be considered. The considerations that are mentioned further in the text have served as guidelines to select the adequate forecasting procedure in the development study of the Port of Poreč.

\section{TRAFFIC PLANNING AND MODELLING}

One of the important elements in the total planning procedure is the decision-making context. The decisions are not made by planning teams (they only 
suggest them) but rather by the appointed representatives of the population of a certain administrative community (state, county, city) who have this right during their mandate. For the results of traffic planning and modelling to be accepted by the decision-makers, they have to gain their confidence. Thus, immediately at the beginning it should be determined whether the traffic planning and modelling procedures are expected to provide a suggestion of strategic or tactical decisions, long-term or short-term measures, rough assumptions of the traffic policy or precise instructions on how to act, solve the traffic problems only or also the issues of the traffic environment, etc.

The availability of high-quality data is also of essential influence on the modelling process. This fact should not be neglected when considering the results generated by the traffic model. Since it relies on the one hand on the general planning data, and on the other hand on the data about the traffic demand, it is obvious that without these two supports the model cannot satisfy the expectations. This issue is especially sensitive in less developed countries that have unsatisfactory basic statistical database, and have even less available specific data that are used in traffic planning. Sometimes it is difficult to arrive at the required data for the current state and even less for the forecast years.

The data on traffic demand are a relatively minor problem since it is expected anyway that they are to be collected during the traffic plan development. As it is known that collecting of this type of data requires substantial consumption of time and human resources, it is extremely useful that at least some of these are collected by the statistical services continuously over many years. In this case there occurs another advantage, which is the possibility of time (tend) monitoring of the flow of certain indicators and characteristics of the traffic demand.

The accuracy of the modelling results is another problem that occurs in the communication between the experienced traffic planners and the decision makers. Those uninformed mainly understand, if not clarified otherwise, that owing to its mathematical and analytical basis the traffic model can serve to produce extremely precise and accurate data on various characteristics of traffic demand. This type of misconception leads to uncritical use of traffic modelling results (with high trust in their reliability) for the purposes for which they had not been intended at all. Later, there is doubt in the purposefulness of modelling when it is found out that the indiscriminately accepted forecast values have not been realized. Therefore, it should be noted that the basic value of the modelling results is in their comparability and impartiality, and not in precision. The possibility of comparison and the impartiality of the modelling procedure are the main planning arguments in order to select among several optional alternative solutions the best one in a relative sense, i.e. to rank the solutions according to adequate ranking criteria without arbitrary or in-advance preferred decisions. Similarly, the modelling enables to objectively determine the time sequence of the necessary interventions into the traffic infrastructure; thus, what has to be done immediately, what should be done in five, ten or twenty years.

Although the planning procedure means gradual bringing of conclusions, the orderers of the traffic plan (study) and the public often expect fast results, and already in the initial phases of plan development they try to extort declarations on the possible traffic solutions. This type of misunderstanding may generate poor communication between the planning team and the public. The draft of the traffic plan is followed by the procedure of its acceptance (which can take months), followed by the implementation which takes years. It should also be mentioned that some administrative units take dozen and more years not starting the development of traffic plans or development studies at all, and then, when this does happen after a long time, they tend to insist on unreasonably short deadlines, which can certainly have negative effect on their quality.

Finally, it is necessary to balance the expectations of the decision makers and the public with professional experiences of the planning team who work with the traffic model. Today, traffic modelling is mainly performed using a number of specialized software solutions for traffic planning. It would be irrational for the planning team to take the risk of getting to know a completely new methodology or software package during the development of the traffic plan (study).

Consequently, in the development study of the Port of Poreč an approach has been selected which ensures two levels of data on the passenger demand in the future on the basis of:

- short-term forecast (for 3-4 years);

- long-term forecast (for the following 10 years).

The terms "short-term" and "long-term" are stipulated here by the possibility of forecast/estimate of the independent variable in the traffic model. The starting point, namely, was the assumption that the model can be used to establish a relation between the volume of passenger demand at the Port of Poreč (dependent variable) and the number of tourists visiting Poreč (independent variable).

Passenger demand has been divided into two segments:

- international traffic;

- domestic traffic (traffic between destinations within Croatia).

Further in the text the traffic models for forecasting of international and domestic passenger traffic are described, as well as the models which are used to 
forecast tourist demand whose results serve as inputs for the previous two models. Global estimate of tourist trends published by the World Tourist Organization (UNWTO) has been used as the basis for the long-term period until 2020. The combination of the forecasting model and long-term estimates make it possible to obtain for a shorter period of time (by 2010) more accurate data that can serve for operative planning and management at ports, whereas the estimates with a range of expected values have been made for investment planning (until the year 2020).

\section{FORECAST OF MARITIME PASSENGER DEMAND IN INTERNATIONAL TRAFFIC}

Forecasting model of passenger demand in international traffic at the Port of Poreč is based on annual data on arrivals of tourists to commercial accommodation facilities in the town of Poreč within the period from 1998 to 2006, and on the data about the number of passengers who have boarded international line and excursion boats during the same period.

\subsection{Model specification}

Demand model for international passenger transport can be presented in the form of regression equation:

$$
\operatorname{LnM} M_{t}=\alpha_{0}+\alpha_{1} \operatorname{Ln} D_{t}+\varepsilon_{t}
$$

where $M t$ is the number of passengers on international tourist lines in Poreč in time $t, D t$ is the number of realized tourist arrivals to commercial accommodation capacities in Poreč in time $t$, and $\varepsilon_{t}$ is a stochastic member. The dispersion diagram has shown that there is non-linearity between the dependent and independent variable, so that the data are transformed using logarithms. The dependent and independent variables are expressed in log-linear form, so that the obtained parameters measure the elasticity of independent variables of the demand function. The growth of tourist demand in Poreč is assumed to have positive influence on the increase in the number of passengers on international lines at the Port of Poreč, and accordingly it is expected that the hypothesis that $\alpha_{1}=0$ will be rejected and that the alternative hypothesis that $\alpha_{1}$ is different from zero at high level of significance will be accepted. One should take into consideration the fact that the independent variable which is included in the model cannot fully explain the movement of the dependent variable, since passenger traffic at the port does not depend exclusively on the movement of the tourist demand at the accommodation capacities, but rather also on a number of other factors such as prices in passenger transport, quality of promotion, avail- ability of free time, purchasing power of tourists, destination attractiveness index, and even the weather conditions. Since many of the mentioned data are immeasurable or not available in the form of statistic indicators (which is the case in the majority of Croatian tourist destinations), the model had to rely on the data that are available. The set of independent variables has been expanded by using the dummy variable which measures the influence of the crisis at Kosovo in the year 1999. However, a low determination coefficient which is obtained when the dummy variable is reduced to the number of passengers has indicated that it explains the very small percentage of passenger traffic variations. The non-significant values of Student statistics and low values of DW test, with the mentioned low determination coefficient, have led to the conclusion on excluding the dummy variable from the model.

\subsection{Assessment of the model and interpretation of results}

The assessment process of the model was based on the "general-to-specific" procedure, which studied the statistical significance of independent variables, and those variables were eliminated that have not proven to be statistically significant. The estimate of the parameters was carried out by the method of least squares (OLS). After having defined the model, the model was tested and the forecasting capability of the model assessed. The best model has been selected by studying the determination coefficient, corrected determination coefficient, t-statistics and DW test.

Table 1 - Model assessment results

\begin{tabular}{|c|c|c|c||}
\hline Coefficient & Value & Standard error & t-value \\
\hline \hline$\hat{\alpha}_{0}$ & -15.1514 & 5.7749 & -2.6237 \\
\hline$\hat{\alpha}_{1}$ & 2.0269 & 0.4441 & 4.5651 \\
\hline
\end{tabular}

Source: author's calculation

$$
\begin{aligned}
\bar{R}^{2} & =0.7126 \\
R^{2} & =0.7486
\end{aligned}
$$

St. estimate error $=0.1809$

$$
\begin{gathered}
F(1.7)=20.8395 \\
D W=1.3615
\end{gathered}
$$

The determination coefficient and the corrected determination coefficient are significantly different from zero, and this is indicated by the high values of F-indicators. F-statistics tests zero hypothesis on the absence of the relation between the tourist arrivals and international traffic at the port. In this case, the calculated value of $F$ statistics is greater than the critical value at the level of significance of $5 \%$, which amounts to 5.59. It may therefore be concluded that the obtained assessments of population regression can 
be a good basis for passenger number forecasting. The results of Student statistics lead to a conclusion that the assessment of parameter along with tourist arrival variable is reliable at the level of significance of $5 \%$, which leads to the conclusion that the tourist arrival variable has significant influence on the dependent variable. This proves also the high correlation coefficient between the number of tourist arrivals and the number of passengers in international traffic, which amounts to 0.8651 .

The results of the Durbin-Watson's test at the level of significance of $5 \%$ have shown that there is no auto-correlation of the stochastic member, since the calculated coefficient $d$ is greater than $d 2$, which leads to the conclusion that the functional form of the regression equation is adequate.

\subsection{Model evaluation}

Table 2 shows the results of the evaluation of the model forecast power carried out on the basis of the values of the average forecast error (MAE), mean value of the absolute forecast error (MAPE), root of the average square error (RMSE) and the Theil's coefficient of inequality $(\mathrm{U})$. The values of all the mentioned indicators have shown that the forecasting power of the selected model is fully acceptable and that the model can be used for short-term forecasting of the total number of passengers on international lines.

Table 2 - Results of model forecast power testing

\begin{tabular}{|c|c|}
\hline Measure of accuracy & Value \\
\hline \hline RMSE & 0.1595 \\
\hline MAE & 0.1292 \\
\hline MAPE & 1.1565 \\
\hline U & 0.0071 \\
\hline
\end{tabular}

Source: author's calculation

RMSE $=$ root mean square error;

$\mathrm{MAE}=$ mean absolute error;

MAPE $=$ mean absolute predicting error;

$\mathrm{U}=$ Theil's coefficient of inequality

\section{FORECASTING MARITIME PASSENGER DEMAND IN DOMESTIC TRAFFIC}

The model for forecasting demand in domestic traffic at the Port of Poreč is based on the annual data on arrivals of tourists to commercial accommodation capacities in the town of Poreč between 1998 and 2006, and on the data about the number of passengers who boarded the domestic lines and excursion boats, as well as ships in transit during the same period.

\subsection{Model specification}

The model of demand for domestic passenger transport can be presented in the following form:

$L n L_{t}=\alpha_{0}+\alpha_{1} L n D_{t}+\varepsilon_{t}$

where $L t$ is the number of passengers on domestic tourist lines in Poreč over time t, $D t$ is the number of realized arrivals of tourists to commercial accommodation capacities in Poreč over time $\mathrm{t}$, and $\varepsilon_{\mathrm{t}}$ is the stochastic member. The data have been transformed by logarithmic computation, since non-linear relation among variables has been determined. The increase in the tourist demand in Poreč is assumed to have positive influence on the increase in the number of passengers on domestic lines and excursion boats at the Port of Poreč; consequently expecting that the hypothesis that $\alpha_{1}=0$ will be rejected and the alternative hypothesis that $\alpha_{1}$ is different from zero at high level of significance will be accepted. The same as in the previous model, it should be kept in mind that the independent variable that is included in the model cannot fully explain the flow of the dependent variable. When the dummy variable for the crisis at Kosovo 1999 is included in the model, the determination coefficient decreases substantially, and the obtained assessments of the parameters are not reliable, so that it may be concluded that the political instability in a wider region did not affect the domestic passenger traffic at the port. All this leads to the conclusion that the dummy variable should be excluded from the set of independent variables.

\subsection{Evaluation of the model and interpretation of results}

The model evaluation process was based on the "general-to specific" procedure which assessed the statistical significance of the independent variables, eliminating those variables that proved to be statistically insignificant. The estimate of the parameters was carried out by the method of least squares (OLS - ordinary least squares). After having defined the model, it was tested and its forecasting capabilities were evaluated. The best model was selected by studying the determination coefficient, corrected determination coefficient, t-statistics and DW test.

Table 3 - Results of model evaluation

\begin{tabular}{|c|c|c|c||}
\hline Coefficient & Value & Standard error & t-value \\
\hline \hline$\hat{\alpha}_{0}$ & -5.3210 & 3.9160 & -1.3587 \\
\hline$\hat{\alpha}_{1}$ & 1.2624 & 0.3011 & 4.1928 \\
\hline
\end{tabular}

Source: author's calculations

$$
\bar{R}^{2}=0.6745
$$




$$
R^{2}=0.7152
$$

St. estimate error $=0.1227$

$$
\begin{gathered}
F(1.7)=17.5880 \\
D W=1.6916
\end{gathered}
$$

The determination coefficient and the corrected determination coefficient are significantly different than zero, indicated also by the high values of F-indicators. F-statistics tests the zero hypothesis about the absence of the relation between the tourist arrivals and international traffic at the port. In this case, the calculated value of $\mathrm{F}$ statistics is greater than the critical one at the level of significance of $5 \%$, which amounts to 5.59. Therefore, it may be concluded that the obtained assessment of population regression may be a good basis for forecasting the number of passengers. The results of the Student statistics show that the assessment of parameter along with the variable of tourist arrivals is reliable at the level of significance of $5 \%$, which leads to the conclusion that the variable of the tourist arrivals has a significant influence on the dependent variable. This is also confirmed by the high coefficient of correlation between the number of tourist arrivals and the number of passengers in domestic traffic, which amounts to 0.8457 .

The Durbin-Watson's test results carried out at the level of significance of 5\%, as well as at the level of significance of $1 \%$ have confirmed the absence of autocorrelation of the stochastic member, which confirms the reliability of the parameter assessment.

\subsection{Model evaluation}

Table 4 shows the results of the evaluation of the forecasting power of the model which is carried out based on the mean value of the absolute forecasting error (MAPE) and Theil's coefficient of inequality $(\mathrm{U})$. The values of the mentioned indicators confirm that the forecasting power of the selected model is fully acceptable, although somewhat worse than the model for international demand, so that the model can be used for short-term forecasting of the total number of passengers on domestic lines.

Table 4 - Test results of the forecasting power of the model

\begin{tabular}{|c|c|}
\hline Accuracy measure & Value \\
\hline \hline MAPE & 9.6987 \\
\hline$U$ & 0.056 \\
\hline
\end{tabular}

Source: author's calculation

MAPE $=$ mean absolute value of forecasting error; $\mathrm{U}=$ Theil's coefficient of inequality.

\section{FORECASTING OF TOURIST DEMAND - ARIMA MODEL WITH INTERVENTION}

In order to carry out a short-term forecast of international and domestic maritime passenger demand, it would be necessary to forecast the flow of tourist demand in Poreč as the main variable which explains the flow of the maritime traffic. Forecasting the flow of tourist arrivals was performed by implementing the ARIMA model with intervention, which takes into consideration the influence of the war activities in Croatia in the period from 1991 to 1995 . The ARIMA or Box-Jenkins methodology is the most widespread method of analysing time series, which is based on the probability, i.e. on the stochastic characteristics of the time series, where the movement of each variable can be explained by its past or time-shifted values and stochastic error. The ARIMA model with intervention is an expansion of the basic multi-variant ARIMA model which encompasses interventions of the independent variable on the dependent variable, in this case war activities.

The empirical analysis is based on the annual data on the arrival of tourists to commercial accommodation capacities in Poreč in the period from 1975 to 2006, monitored by the State Office for Statistics. Considering the graphical presentation of the flow of tourists in Poreč from 1975 to 2006 one may notice the non-linearity and the rising trend of arrivals, followed by sudden and powerful external interventions in 1991 and 1995, followed again by an increasing trend. In order to take into consideration the mentioned phenomena the intervention ARIMA model has been defined with multiple sudden interventions that had permanent effect on the flow of the time series.

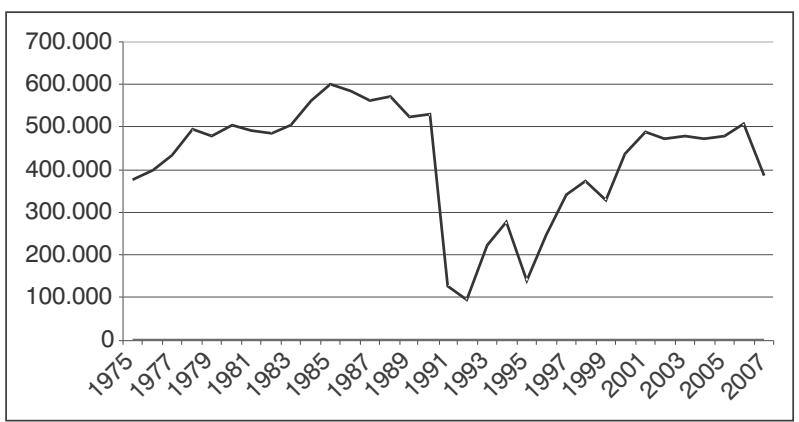

Figure 1 - Tourist demand in Poreč in the period from 1975 to 2007

Source: DZS data, processed by the authors

\subsection{Testing of time series characteristics}

The implementation of the ARIMA model is possible only if the considered time series are stationary or if they become stationary after one or several differ- 
Table 5 - Results of ADF test of unit roots

\begin{tabular}{|c|c|c|c|c|c|c||}
\hline & t-value & ADF critical values* & $\mathrm{R}^{2}$ & F-test & DW & Akaike criterion \\
\hline \hline $\log \mathrm{Yt}$ & -2.3082 & -2.9571 & 0.1508 & 5.3278 & 1.7406 & 7.1462 \\
\hline$\Delta \log \mathrm{Yt}$ & -5.9738 & -2.9639 & 0.6009 & 20.3268 & 1.8676 & 0.0806 \\
\hline
\end{tabular}

*At the level of significance of 5\% the MacKinon (1996) critical values are implemented.

Source: author's calculation

entiations and stationary time series are those that have constant mean value and variance over time. By considering the autocorrelation correlogram function (ACF), partial autocorrelation function (PACF), and the analysis of variances and mean values it is concluded that the time series of the arrival of tourists to Poreč is not stationary, which means that before implementing adequate ARIMA model the data have to be transformed into the stationary series by differentiation. In order to eliminate non-stationary characteristic of the variance, the data have been transformed by using logarithms, in turn being tested for the existence of unit roots. In order to test the stationary characteristic of the time series and to determine the level of differentiation, apart from the study of the correlogram, the expanded Dickey-Fuller test (ADF) is carried out for the existence of unit roots. If zero hypothesis on the existence of unit root is accepted, the series are non-stationary, i. e. the series retains the non-seasonal unit root. The assumption on the existence of the unit roots is based on $t$-statistics by using simulated critical values.

The values of ADF test before differentiation were greater than the critical values at the level of significance of $5 \%$, so that it is not possible to reject the hypothesis on the non-existence of the unit roots. This means that after logarithmic computation the time series remains non-stationary. After differentiation, the ADF statistics is significant at the level of significance of $5 \%$, which leads to the rejection of the zero hypothesis on the existence of the unit roots. This is contributed also by the low values of Akaike criteria and Schwartz criterion, and high values of determination coefficients and DW statistics. Therefore, the time series has to be computed logarithmically, but also differentiated in order to create the conditions to apply the ARIMA model.

The best model was selected on the basis of the statistical significance AR, MA and intervention coefficients at the level of significance of $5 \%$ and non-existence of the series correlation of residuals by using Akaike information criteria (AIC) and Schwarz Bayes criterion (SBC).

\subsection{Model definition}

The intervention model before data transformation is formulated as a regression function which con- sists of independent variables in the form of the ARIMA model and intervention function which contains two dummy variables:

$Y t=C+\sum f(I t)+N t \quad t=1, \ldots, T$

where $Y t$ is the number of tourist arrivals, $C$ is a constant member, $\sum f(I t)$ is intervention function over time $\mathrm{t}$, and $N t$ is a stochastic member.

Dummy variable $I t$ is used for two types of interventions, the first of which measures the influence of war activities that started in 1991, which were sudden and had permanent effect, and the latter measures the influence of war activities of 1995 which had short-term effect on the time series.

The final form of the model after transformation of time series can be written in the following manner:

$\Delta^{d} \ln Y_{t}=C_{1}+\sum_{i=1}^{n} \omega_{i} \Delta^{d} I_{i t}+\frac{\theta_{q}(B)}{\phi_{p}(B) \Delta^{d}}$

where $\Delta^{d} \ln Y_{t}$ is the time series which has been transformed by logarithmic computation, and then differentiated $d$ times, $C_{1}$ is the constant which encompasses the deterministic trend of data, $\omega_{i}$ is the parameter of intervention influence, $I_{i t}$ are interventions with significant parameters, $B$ is the shift operator, $\theta_{q}(B)$ is the process of moving average of order $q$ or $M A(q)$ such that $\theta_{q}(B)=\left(1-\theta_{1} B-\theta_{2} B^{2}-\ldots-\theta_{q} B^{q}\right)$ is the autoregression process of order $p$ or $A R(p)$ such that $\phi_{p}(B)=\left(1-\phi_{1} B-\phi_{2} B^{2}-\ldots-\phi_{p} B^{p}\right)$, and $\alpha_{t}$ is the estimate error which is independently and equally distributed with mean value equal to zero and constant variance. The estimate error represents the component of random shock which cannot be predicted by the ARIMA process.

\subsection{Evaluation of the model and interpretation of results}

The analysis of residuals encompassed an overview of ACF and PACF functions and carrying out the Box-Ljung test for common significance of residual autocorrelations. The asymptotic $t$-test was used to test the statistical significance of individual coefficients. The unknown parameters have been estimated by the method of least squares. Based on the mentioned indicators three possible ARIMA models have been selected, and the final selection of the model was based on the compromise between the principle of introducing a minimal number of parameters into the 


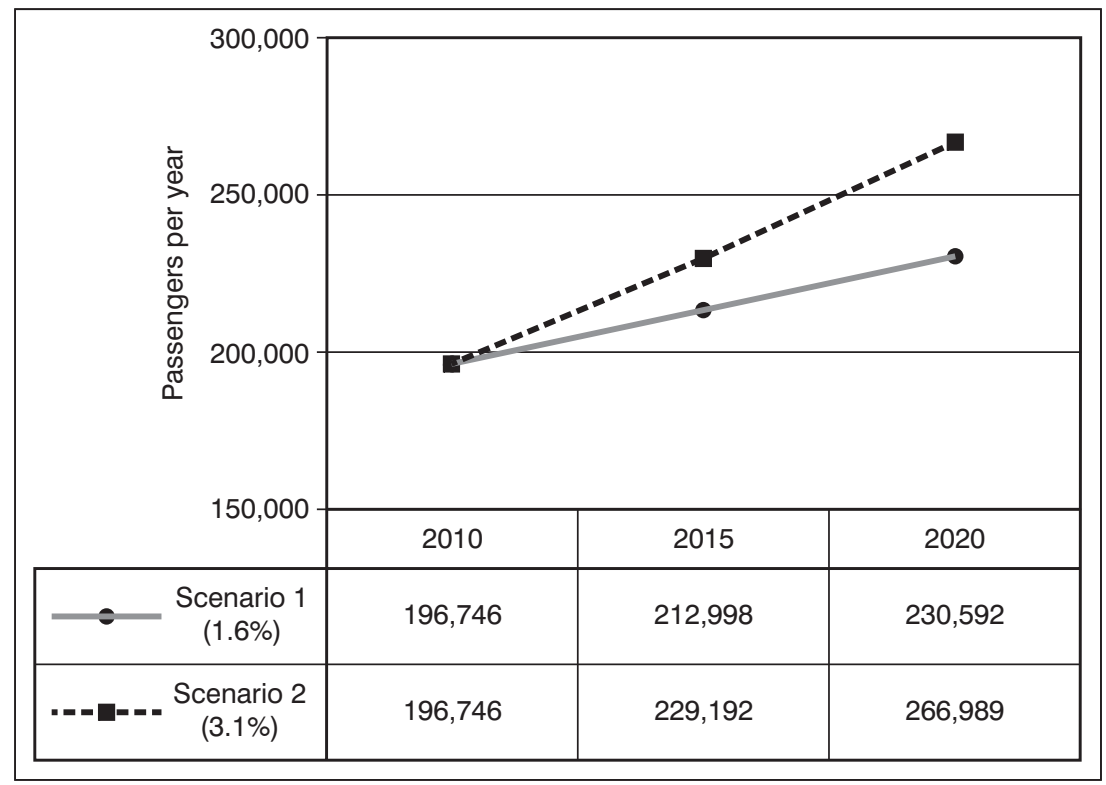

Figure 2 - Forecast / estimate of passenger demand at the Port of Poreč according to different scenarios

Source: authors

model and the success of the model measured by the amount of corrected determination coefficient. According to all the evaluation criteria the ARIMA model $(1,1,1)$ proved to be the best, and its results are presented in the Table. The analysis of residuals has shown that the model is good and that it may be used for forecasting. The constant member was not found to be significant and was therefore eliminated from the model.

Table 6 - Evaluation results of ARIMA model with intervention

\begin{tabular}{|c|c|c||}
\hline \hline ARIMA model & Coefficient & t-value \\
\hline \hline AR1 & 0.8647 & 4.4138 \\
\hline MA1 & 0.6689 & 2.274 \\
\hline$\omega 0$ & -1.5347 & -6.9633 \\
\hline$\omega 1$ & -0.8982 & -3.5913 \\
\hline
\end{tabular}

*AR is auto-regression coefficient of order 1, MA coefficient of moving aver age of order $1, \omega ́ 1$ coefficient of intervention of the year 1991, and $\omega 2$ is the coefficient of intervention of the year 1995

Source: author's calculation

\section{LONG-TERM ESTIMATE OF MARITIME PASSENGER DEMAND}

The number of passengers for 2010 was obtained by previously described passenger demand forecasting models, with independent variable forecast on the basis of the ARIMA model. The values for the next ten years have been estimated on the basis of UNWTO data on future tourist trends in Europe, since the tourist demand in Poreč is the most important variable which explains the flow of passenger demand at the Port of Poreč. The world tourist organization (UNWTO) estimates that in 2010 there will be 527 million tourist arrivals realized in Europe, and in 2020 - 717 million will be realized. The estimated annual growth rate of tourist demand until 2020 for Europe amounts to $3.1 \%$. If this growth rate is implemented for Poreč with the year 2010 as the reference year, the flow of passenger demand until 2020 may be estimated (Scenario 2). A somewhat more conservative estimate, which takes into consideration that the Mediterranean destinations of sun and sea will have lower growth rates due to the saturation of such destinations and the expected increase in the trips to long-distance destinations, is carried out with average annual growth rates of $1.6 \%$ (Scenario 1). The estimated long-term passenger demand is presented in Figure 2 with expected values between the lines that describe both scenarios. Naturally, the range of expected values expands for the later years, which indicates a decrease in the reliability of the estimate, which has to be taken into consideration when making long-term decisions.

\section{CONCLUSION}

Models described in this paper have been developed for the requirements of forecasting passenger demand at the port of a tourist destination. As in many other cases, the availability of data which could be used as the basis for the forecast was very limited. It was therefore necessary to define models which, on the one hand, are simple regarding the required input, 
and, on the other hand, sufficiently reliable in order to satisfy the goals of a development study. The limitation should also be noted, resulting from the impossibility of reliable forecasting of the tourist demand over a long term due to high sensitivity of this variable to unpredictable external conditions. As statistically proven that this variable has decisive influence on the maritime passenger demand at the tourist destination, the reliability of forecasting / evaluation of its values determines to great extent the quality of forecasting / evaluation of the passenger demand. In this context, the combined implementation of the forecast models for short-term period with expert estimates for a long-term period has proven to be the optimal solution.

\section{Dr. sc. DAVOR KRASIĆ}

E-mail: davor.krasic@iztzg.hr

Mr. sc. PETRA GATTI

E-mail: petra.gatti@iztzg.hr

Institut za turizam

Vrhovec 5, 10000 Zagreb, Republika Hrvatska

\section{SAŽETAK}

\section{METODOLOGIJA PROGNOZIRANJA POMORSKO-PUTNIČKE POTRAŽNJE U TURISTIČKOJ DESTINACIJI}

Prognoziranje pomorsko-putničke potražnje je zadatak koji se gotovo uvijek pojavljuje u razvojnim studijama putničkih luka, kako zbog operativnih tako i zbog investicijskih potreba. Ako luka pripada turističkoj destinaciji, onda postoji razumljiva namjera da se prognostičkim modelom uspostavi ovisnost između putničke i turističke potražnje. Kako pouzdanost prognoziranja u velikoj mjeri ovisi o kvaliteti i raspoloživosti podataka, prognostički model je često puta kompromis između teo- retskih postavki i praktičnih mogućnosti. U ovom radu opisan je pristup prognoziranju pomorsko-putničke potražnje na primjeru turističke destinacije Poreč, koja je niz godina po turističkom prometu najjača destinacija u Hrvatskoj. Prezentirani prognostički modeli mogu poslužiti kao jedna od smjernica za daljnje istraživanje odnosa između prometa i turizma.

\section{KLJUČNE RIJEČI}

prognoziranje pomorsko-putničke potražnje, prognoziranje turističke potražnje, promet i turizam

\section{LITERATURE}

[1] Studija dugoročnog razvoja luke Poreč (Long-term development study of the Port of Poreč), Institute of Tourism Zagreb and Faculty of Maritime Affairs Rijeka, Zagreb, 2008

[2] Ortuzar, J. D., Willumsen, L. G.: Modelling Transport, John Wiley \& Sons, Chichester, 1994

[3] Krasić, D.: Prometno planiranje i prometni modeli, 2nd Croatian Congress on Roads, Cavtat, 1999

[4] Goh, C., Law, R.: Modelling and forecasting tourism demand for arrivals with stochastic nonstationary seasonality and intervention, Tourism Management, Vol. 23, No. 5, 2002, pp. 499-510

[5] Granger, C. W. J., Jeon, Y.: Long-term forecasting and evaluation, International Journal of Forecasting, Vol. 23, No. 4, 2007, pp. 539-551

[6] Makridakis, S., Hibon, M.: ARIMA models and the Box Jenkins methodology, Journal of Forecasting, Vol. 16, 1997, pp. 147-163

[7] Pindyck, R. S., Rubinfeld D. L.: Econometric Models and Economic Forecasts, McGraw-Hill International Editions, New York, 1998

[8] Song, H., Witt, S. F.: Tourism demand modelling and forecasting, Pergamon, Oxford, 2000 